\title{
一山岳トンネルの地下水問題を主対象としたー 私の地質工学への実学的挑戦
}

\author{
大島洋志* \\ My Practical Challenge to Engineering Geology \\ towards solutions for groundwater \\ problems in mountain tunnels
}

Hiroshi OSHIMA *

\section{1．まえがき}

平成17年 5 月に栄えある地下水学術賞をいただ いた際に、『山岳トンネルと地下水』と題する㧈 話しをし、その要約が学会誌に揭載されてからは や 3 年になります。その時は、私の還暦記念自費 出版本の中の話題をもとに構成し、最後に、今後 は語り部に徹するつもりであることを記しまし た。

この 3 年はその気概でやってきたつもりでした が、まだ努力が足りないとみえて、今回、新たに にトンネルを中心とした地下水問題について、何 でも思うところを書いて欲しいとの依頼を受けま した。

65歳という年齢は、現役バリバリの方々にとっ ては十分に年寄りなのですが、私どもが扔付き合 いしている諸先輩は大変に㧍元気な方々が多く、 私の世代はまだまだヒヨコ扱いであり、居心地が 悪く、まだまだ遺言もどきを書くには早すぎると いう気もいたしますが、素直にご下命に応えるこ とにしました。といっても、私自身変わりようが ありませんので、今日まで私の周りでいろいろと
抄教えを頂いた先輩や同輩、後輩の皆様方へ感謝 の気持ちを表しつつ、「現場主義に徹底した実学 を目指せ」というこれまでの主張に沿って話を展 開することにいたします。

\section{2. 国鉄入社のきっかけとなった本との出会い}

大学 4 年に進級しますと、就職のことを考える 必要があります。そういう時期、たまたま本屋で 『トンネル技術者のための地質学』『湧水と地圧』 という 2 冊の本が目に入りました。著者の所属は 鉄道技研地質研究室とあり、地質屋が国鉄の中で 活躍できる場があることをこの本から知りまし た。

開業直前であった東海道新幹線は、そのうち九 州博多まで延伸されると聞いておりましたので、 地質技術者としてこういった仕事に関われたら楽 しいだろうなと思いました。講座の松本達郎教授 に相談しましたところ、著者のお一人宮崎さんは 大学の一期後輩だから聞いてみましょうと言って いただき、 $4 \sim 5$ 年に一度しか地質屋は採用され ないというなか、たまたま採用予定があるらしい 
とのことで受験いたしましたが、7人も受験者が おりましたので、恐らく駄目だろうなと諦めてお りましたが、何故か採用とあいなりました。受験 の動機を聞かれた際に 2 冊の本のことを話したの がきっと効を奏したのだろうと思いました。とい うこともあって、最初のきっかけを作り、かつ運 を開いてくれた 2 冊の本に感謝しております。

\section{3. 丹那㯌道の難工事が鉄道地質屋採用の契機}

鉄道に地質屋が入るきっかけとなったのは、16 年の歳月（1918～1933年）をかけて完成した東海 道本線の丹那トンネルの難工事であったようで す。

鉄道地質屋の誕生は丹那の工事が始まって 6 年 後の1923（大正12）年度でして、東京帝大卒の地 質理学士三人が一緒に鉄道省（熱海線建設事務 所）に入っています。そのうちの一人渡邊を貫 （1898～1974）は、『地学事典』や『地質工学』な る名著・大著を世に出された偉人であります。私 は鉄道の後輩としてこの雲上人に昖会いすること はありませんでしたが、今なお後学の者が参考に できるこの名著を通して、例えば、現場の実例を できるだけ公に残しておくことの重要性を教えら れるなどしていますので、大先輩の薫陶に浴して いる気分になっております。

\section{4.現場を経験することの重要性}

社会人になって40数年、何故か今なお、いろい ろな相談を受けております。それは、現場が困っ ている問題に対して、いわゆる空理空論ではな く、実用的な助言をしてくれるからた、と言われ たことがあります。当の本人はごく当たり前のこ ととして対応しているのですが、もしも、この姿 勢が評価されているのであれば、その原点は間違 いなく『若い頃の現場経験』だといえま。そこ で、私の今日を方向付けしてくれたであろう二十 歳代の頃の現場経験 2 例を紹介します。

\section{（1）六甲でトンネル湧水のイロハを学ぶ}

国鉄に入社した当時は、『ひかりは西へ』の キャッチフレーズのもと、第一期として岡山まで の山陽新幹線建設が始まろうとしておりました。
その中で、阪神間の市街地背後にある六甲山地 を縦断する六甲トンネル $(16,250 \mathrm{~m})$ は大規模な 断層破砕帯があり、トンネル工事における最大の 難工事になると懸念されておりました。鉄道地質 屋としての私の一歩はこの六甲トンネルの水調査 から始まりました。

大学を出てすぐの頃です。地質と地下水とがこ れほど密接に関係しあっているという認識は全く ありませんでした。何故地下水の問題を我々地質 屋が担当するのだろうかという疑問を抱いたもの です。しかし、携帯三角堰や電気伝導度計などを 持って六甲の南山麓の水文地質調查を行っている うちに、沢の流量や水質にはトンネル工事に必要 な地質情報が少なからずあることが分かるように なりました。

その調査の最終的な目的はトンネル竣工後の湧 水量を予測するということだったのですが、それ を恒常湧水量と呼ぶこと、そして、それは季節に は無関係に変動が少ないことを学びました。その 恒常湧水量の予測法は、高橋彦治氏（当時、鉄道 技研地質研究室長) が、当時日本最長のトンネル として開通した北陸トンネル $(13,870 \mathrm{~m})$ の業務 に従事しながらそれを題材にして提案された学位 論文であったことを知り、現場で問題を発掘して いくことの大切さと併せて仕事の結果を論文とし てまとめ、40歳までには学位を取得するくらいの 積もりで仕事に臨まなければならないことなどを 教えられました。

しかし、一方で、工事の担当者は、いつ、どこ で、どの程度の湧水があるかが一番知りたいので はないのかな？と現状の調査レベルを向上させる 必要性も感じることができました。

\section{（2）福岡トンネルで湧水・渇水問題の実体験をする}

地質屋も現場を経験する必要があるという、当 時の国鉄建設陣の大方針があったのだと思います が、国鉄入社 6 年目に、山陽新幹線建設の現場長 を拝命致しました。地質の専門家という小世界に 閉じ籠もることなど許されない環境に置かれたわ けです。担当区間は福岡県の遠賀川以西、鞍手郡 下の約 $12 \mathrm{~km}$ 間でした。地下に石炭採掘跡がある 筑豊の山を貫くトンネルが 2 本もあり、炭鉱鉱害 問題に詳しい九大にパイプをもった地質屋がいる と、何かと便利というのが配属理由の一つだった 
と思います。ところが、工事が進展していき、福 岡トンネルから大量湧水が連続する事態となって 以降、この解決が私に科せられた最大の課題と変 わっていきました。

山陽新幹線の昭和 50 年春博多開業という最終目的 を果たすために、与えられた権限の中で自分は今 何をなすべきなのか？といった姿勢で仕事に臨む 必要があることを実感できました。このときの 2 年半の貴重な現場体験（特にトンネル水問題での 苦労）が、今の私を作ってくれたことは間違いあ りません。そこで学んだ主な現場経験は、次のよ うに整理できます。

- 毎分 $23 \mathrm{~m}^{3}$ の大量湧水で切羽が崩壊、博多開業 の最大のネックとなるというプレッシャーを受 ける。その工程挽回のため本坑両側の水抜坑、 切羽前方への高速の水抜きボーリング、坑内強 制排水を 3 点セットとする工法を採用するとと もに、崩壊した切羽から $2.5 \mathrm{~km}$ 前方の沢部に深 度 $110 \mathrm{~m}$ の立坑を追加施工するなどを体験。ま た、併せて、崩壊切羽部や立坑施工でも地盤強 化や止水目的の注入を実施し、その難しさを体 験。

・坑内への大量湧水が周辺の農業・生活用水など の水利用へ影響を与え、その解決のための地元 協議で悪戦苦闘。工事に起因する渴水問題の解 決が工事の死命を制することを嫌になるほど実 感。また、この種の問題解決のためには、トン ネル湧水を降水や地表水と密接に関連したもの として水収支的に捉える必要のあることを実 感。

・最後に、工事を円滑に進めるためには、身内、 施工業者、そして地元との人間関係を良好に保 ちつつ、先手々々で、飴と鞭を上手に使い分け ていかねばならないといった社会学・人間学を 体験。

\section{5. 現場が抱える問題を解決してやることの重要性}

2 年半の貴重な体験をした後、鉄道技研に戻り ました (本社建設局も兼務)。以後は直接的に現 場勤務することはなくなりましたが、建設中のト ンネル現場だけでなく、供用中のトンネルや斜面 のメンテナンスに関わる多くの現場の技術指導、 ならびに今後整備されるべき整備新幹線や中央新 幹線の路線計画に地質・トンネル技術者として関
わる機会が与えられました。また、国鉄だけでな く、鉄道建設公団が進めていた青函トンネルや上 越新幹線などのトンネル建設現場などを見せてい ただく機会も与えられました。

また、この頃からトンネル技術や地質調査に関 わる学協会業務を通して、鉄道以外の方々とのお 付き合いできるようになり、さらに広い視野、一 歩下がった視点でものごとを判断できる機会を与 えられました。

私は、そういった現場など抱える箇々の問題解 決に対する助言をする一方で、それらの問題の中 に自分が貢献できる長期的な課題はないだろう か? という姿勢で臨んだつもりです。こういう観 点で取り組んだ事例を三つ紹介します。

\section{（1）塩嶺トンネルの現場問題を解決しつつ、水文 地質調査法の体系化やトンネル水収支シミュ レーション手法を提案}

30歳前後の頃の私の最大の課題は中央本線岡 谷・塩尻間を短絡する塩嶺トンネル $(5,994 \mathrm{~m})$ の 水問題でした。これまでの経験を活かし、私の力 の大部分をこのトンネルへ集中させることとなり ました。ここで実施したことは次のようなもので す。

- 地下水位や河川流量の変化をトンネル工事の進 渉\&降雨量の変動との関係で水収支的に計測。

- 水田用水の尺度として用いられる減水深、土壤 水分の変化を測定する $\mathrm{pF}$ 值などを計測に導入。 ・地下水の受血としての地質構造を広域に把握す る必要性を主張し、電気探査法や、500m 超の 多数のボーリングの他に浅層反射法を試用。植 生活力度調査法としてリモセン手法も試用。

・これらを通して、『トンネル掘削を対象とした 水文調查法の研究』により、水文地質調査法を 体系化し、以後のトンネル地質調査に適用。

・トンネル掘削に伴う周辺水収支の変化を予測す る独自のシミュレーション手法を開発し、計画 中の整備新幹線等の路線選定調査に適用する。

・トンネル工事を対象とした水文地質学的調査・ 研究で九州大学から理学博士の学位記を取得す る。

そして、この業務成果を、平行して担当してい た整備新幹線や中央新幹線の路線選定業務などに 使うなどして、そのレベルアップを図りました。 
（2）スラブ軌道トンネルの路盤噴泥対策に取り組む

山陽新幹線は、軌道構造を従来のバラスト軌道 からスラブ軌道へと一大変換させた新幹線でし た。ところが、昭和50年、念願の開業を果たして 間もなく、岡山以西に数多くある花崗岩マサ地山 中を貫くスラブ軌道トンネルに軌道狂いがみられ るようになりました。現場調査の結果、列車走行 時に地下水で飽和された路盤コンクリート下の間 隙水圧が異常に上昇し、打ち継ぎ目などから細粒 の土砂を伴った水が噴出し、そのため、徐々に路 盤コンクリート下の空隙が拡大し、軌道狂いへと 発展していくものと判断しました。

そして、在来線トンネルにおける同種の問題を 解決させた経験をもとに、路盤下の空隙を充填の うえ、中央通路下に排水溝を追加施工するという 応急対策（恒久対策とはいえない）を採ってもら い、それなりの効果をあげることができました。

この経験は、地下水の豊富な砂質地山のトンネ ルではインバートの下面には排水溝は設けないな ど、土砂の流出を防止する設計的な配慮に生かし ました。そして、シラス地山トンネルにおける路 盤の水問題処理にも活かしました（(3)-i で後 述)。

（3）九州新幹線のトンネル路線選定やシラス地山 トンネルの設計・施工法に関わる

2004（平成16）年春に開通した九州新幹線鹿児 島ルートには、自分が九州の出身ということもあ り深く関与してきました。その中から 2 例を紹介 します。

\section{i : 水に弱いシラス地山中のトンネルの路線選定 と路盤噴泥対策を考慮した水砕スラグの採用}

シラスは一般の土粒子と比べ、非常に軽く、水 浸食に弱い地質です。鹿児島ルートは終点方に約 $20 \mathrm{~km}$ のシラス区間があり、その半分以上が地下 水面下のトンネルとして計画されていました。そ こで、種々検討の結果次のような配慮をしまし た。

・最大 $35 \%$ の縦断勾配を使うことで、地下水面下 となるトンネル長の短縮 $(11.5 \mathrm{~km} \Rightarrow 7 \mathrm{~km})$ と 最大水頭の低下 $(70 \mathrm{~m} \Rightarrow 20 \mathrm{~m})$ を実現させた。

・透水性が良く、適当な強度がある水砕スラグに よる透水性路盤の採用を提案し、現場実験を経 て、施工法ならびに施工管理法を確立し、実用
に供した。

・シラス地山の自立性と水砕スラグの確実な養生 のためのウェルポイントの有効な適用を図っ た。

この一連の施策によって工事は無事終了し、土 木学会からは技術賞という栄えある賞を頂戴し、 満 4 年を経過した現在も、トラブルを起こすこと なく供用されており、関係者からも喜ばれており ます。

\section{ii : 筑紫トンネルの路線選定}

九州新幹線の博多以南には、福岡 ·佐賀両県に またがる $1,000 \mathrm{~m}$ 級の東西方向の稜線をもつ背振 山地が障壁となっています。この山地を南北方向 に横断する筑紫トンネルの計画においては、博多 駅から車両基地までは、既設路線が南下していま すから、その先をどうするかが問題でした。

背振山地の地質は花崗岩で、周辺自治体の水瓶 的役割をもっています。いろんな路線が考えられ ましたが、真っ直ぐに大きな土被りで貫くという 当初の案を避け、東側の山裙沿いに小さな土被り で迁回する案と西側迂回案とを比較検討しまし た。最終的に、水利用の比較的少ない西側に迂回 しつつ、新幹線規格の許せる範囲で極力施工基面 を上げて地下水頭を小さくなるように配慮するこ とで、水環境問題への影響の度合いを少なくでき る西側案を推薦し、この案を取り上げてもらいま した。

国鉄民営分割10数年後に着工した筑紫トンネル は2007 (平成19) 年11月に大きな水問題を生じるこ となく無事貫通し、関係者に感謝して貪えました。

\section{6. 社会に何らかの形で貢献できる学問を目指そ う(実学への挑戦)}

50歳で第二の人生に入ってから既に 15 年が過ぎ ました。この間 $\mathrm{OB}$ 活動をしながら、自分の専門 領域の学協会活動にも力を入れてきました。これ らの活動は選ばれること自体、ある面名誉なこと ではありますが、決して楽なものではありませ ん。若い時代にお世話になったことへの恩返しと いう気持ちがなければとても務められないと思い ます。

相変わらず、水で苦労しそうなトンネルの設計 
や施工法に関する相談を受けておりますが、その 頻度は以前よりもずっと多くなっています。本当 に有り難い話で、私自身の生き甲斐ともなってお ります。

何らかの形で役立ちたいな！と思いつつ、(1)現

場に解決を要する技術的問題はないか? (2)それら の問題解決に自分の専門を少しでも活かせること はないか? という姿勢を貫いてきたから、こうい う有り難い人生を送れているのだと思っておりま す。

気恥ずかしさを覚えますが、参考にしてもらえ るところが少しでもあれば幸いとの思いで、私の 仕事に対しての人生訓的な言葉を以下に記してみ ます。

\section{（1）見れども見えず}

経験や勉学の積み重ねがある人とない人が、同 一の現場や事象に遭遇し、それを目の辺りに見た としても、その意味するところが一方には見える が、一布には全く見えないものなのです。しか し、見えないからといって悲観してはなりませ ん。勉学を重ね、経験を積むうちに徐々に何かが 見えるようになるものなのです。でも、それだけ にとどまっていてはなりません。さらに磨きをか ける努力をし続ける気概が必要です。付加体地質 の提唱者として有名な九州大学の恩師勘米良亀齢 名誉教授から吒き込まれた教えです。

\section{（2）地相は人相山の性状}

トンネル十訓という教えの中で最初に出てくる 言葉です。地形的特徵のなかには地下の地質性状 を推定できるものがあるから、ただ漫然と地形を 眺めてはいけないよ! 見えるようになる努力が必 要だよ!という教えなのです。（1）の教えとも繋 がりますし、この知識は下記（3）や（4）の想像 作業の強力武器にもなるのです。

\section{（3）トンネルセンターを歩こう}

トンネルの計画や施工に際し、路線周辺の状況 を把握しておくことは大切です。戦前のトンネル 路線計画においては、工事責任者等が中心となっ て自らが山を甜めるように踏破し、問題点を実感 しつつ最終決定を下していたそうです。分業化が 進んだ現在でもなお、工事の責任者たるもの、全 域把握はともかくとして、せめてセンター位は歩 いて担当しているトンネルの地形・地質を把握し
ておう必要を説いた、鉄道の大先輩高橋彦治氏か ら教わった言葉です。

\section{（4）点から線へ、線から面へ・・・}

地形・地質情報には点や線または面的なものが ありますが、一般に得られる情報は一次元の点情 報が大部分です。しかしこれらの情報はただ漫然 とあるだけでは無意味なのでして、常に地形学・ 地質学的素養で全体像（線 $\Rightarrow$ 面 (二次元) $\Rightarrow$ 立体 (三次元)）を想像しながら組み立ててみなければ 意味をなしません。

\section{（5）観測・修正法に基づくのが地質調査の基本}

情報が増えていくと、上記（4）の三次元的想 像作業は新たにやり直してみる必要があるので す。これが地質調査の基本であるということを忘 れてはなりません。

\section{（6）事実と解釈の峻別}

上記の想像作業で得た成果はあくまでも「解 棌」です。新たな地質的情報が加わる度に行う作 業において、この「解釈」を基礎情報（事実）と して扱ってはならないのです。これって、実社会 では意外に峻別されずに使われており、要注意な のです。

\section{（7）自分の目と耳で確かめたものを大切に}

情報には自分が直接得た以外にも、自分の周 囲、論文や杂誌、新聞あるいはネットなどから得 られる様々な情報がありますが、それらを一様な レベルで扱うのではなく、自分が直接得た情報 （経験も含む）を最も価值ある一級のものとして 扱うのが、間違いの少ない結果を導いてくれるも のと思います。

\section{（8）逆解析を過信するな（いい加減な観測データ はない方がまし)}

最近は何事も計算機を通してみなければ、安心 できない時代になっています。観測データをもと に逆解析で必要な諸定数を求め、それをもとに行 う計算で今後の状態を予測するという方法が一般 化しております。しかし、意外といい加減なデー タがあるのが現場の実態なのです。そういう実態 を知らずに、一級の基礎データだと信じて得られ た逆解析は、実態とかけ離れたものになることが 多いのです。計算の結果が、まともなものかそう でないかの判断は、多くの現場経験に裏付けられ た勘が必要です。したがって、計算機による解析 
等は、その対象業務が結論に至るまでの間に経験 者の判断や評価がなされていない、㧍飾りにしか 過ぎないような無駄な使用は避けるべきです。

\section{（9） OB 情報（古老情報）は活用しよう 衆知を 集める}

自分よりも長い経験を踏まれた $\mathrm{OB}$ や古老の意 見の中には、素晴らしい知恵が含まれていること が多いものです。自分が判断に困っているとき、 その知恵の一部を活用することで、難局を打開す ることができることが往々にしてあるものです。

また、自分一人の判断ではなく、监知を集めて 出した結論の方が、良い結果になることが多いも のです。

\section{（10）まず実行、理論はあとから付いてくる（経験 工学的発想)}

私が経験したトンネル現場は経験の積み上げで あって、学校で学んだ学問だけでは処理できない 実戦の場であるのだとよく聞かされました。現場 ではいろいろな難問が起きますが、その都度試行 錯誤しながら解決していくのです。もち万ん学問 的な知識をべースにした作業ではありますが、 「四の五のと、屁理屈ばかり言ってないで、先ず 実行」「下手な考元休むに似たり」「下手な鉄砲も 数撃ちゃ当たる」「当たらずといえども遠からず」 といった精神で応急措置をとりながら進めていく ことが多いのです。

しかし、それで終わりではなく、これらの成功 例と失敗例は、後々のために、何故そうなったの かについて分析・検討し、それを理論の域まで高 めて㧍くという作業が当然のこととしてなされる のです。こういう仕事の進め方って、意外に世の 中にはあるのです。

\section{(11)聞き上手}

「部下の話は十分に聞いてあげるもんだよ」、と 上に立つ者の心得の一つとして教わりました。部 下の意見をよく聞きながら、良い方向へ導いて行 くという姿勢は、彼らの信頼を獲得でき、結果と して良い仕事に繋がるものです。

これとは趣旨を異にしますが、自分自身が仕事 で迷路に大りこんだ時、何で悩んでいるかを誰か に聞いてもらう機会を作ったものです。聞き役が 何か言ったわけでもないのですが、話をしている うちに、意外と自分の頭の中が整理され、問題の
解決策が見えてくることが良くありました。聞い ている人よりも話している本人の方が真剣に悩ん でいるだけに、何が足りないかとか、何が理屈に あっていないかが、明瞭になってくるからだと思 います。この方法、案外に効果があるものです。 自分に意見をしてくれる人を大切にするのは当然 のことですが、話を然って聞いてくれる人を持つ ということも大切なのです。

\section{(12) 60点主義、Quick Response}

工期を過ぎた100点は価值がなく、それよりは 例え60点でも工期内に納めたものの方に価值があ る場合が多い、と吒き込まれたものです。工期に は縛られずに100点のものを納めるというのが、 職人気質の世界では優れているという見方が一般 的かと思いますが、そういう考光の否定で、工期 至上主義の教えです。とにかく、工期を守ること を第一にし、守れそうにない場合は、仮納品の形 でも良いから成果品を出して拉きなさい。もし、 許してもらえるなら、許された時間のうちに満足 できるものにしたうえで、差し替えてもらいなさ い。何事も Quick Response で、㧍客様とは常に 意志の踈通を図りつつ、現状（進渉状況）をその 都度報告しながら作業を進めなさい、というもの でした。

\section{(13)捨てる神あれば拾う神あり}

人間関係がうまくいかないことってよくありま す。上司などとの折り合いがうまくいかず、最悪 辞めなければならないような事態になったとして も、蓼食う虫も好き好きといいますが、一方でそ の性格を好きになってくれる人もいるものです。 職場を替える（上司を替える）ことで、能力が開 花することだってよくある話です。うまく行って いないときでも、天は決して見捨てないものだと の意識をもつことができればノイローゼにならな くてもすむのではないでしょうか。

\section{(14) 最善次善次々善}

国鉄入社まもない頃、どこか有名な扮寺（場所 は思い出せません）の境内に「最善次善次々善…」 という教えが書いてありました。直面している問 題の解決を図万うとする場合、最善と思われる方 法をとるのが良いのだが、それが適わないことっ てよくあるものです。その時点で採用できる実現 可能なものに挑戦するのが結局は最善の策になる 
のだという教えですが、意外なところでしかも安 い㧍賽銭で人生の教訓を授かって得した気持ちに なりました。

\section{(15) 原点に戻れ}

「どうしたら良いか、判断に迷うことがあった ら、原点に戻って考えれば、自ずから答えは出て くる」という、原点回帰主義の教えは、50歳に なって国際航業(侏に入社した当時の友納社長から 教わった言葉として今なお新鮮に記憶しておりま す。

この他、（16）温故知新、（17）何でも興味をも とう、(18）多くの人と付合おう、(19）一期一会 を大切に、といった人生訓を大切にこれまでを生 きて参りました。

狭い専門領域での常識が、実は別の世界では非 常識であるってこと、よくあります。自分の専門 ではないからといって逃げないこと、自分の専門 外の方々とも大いに付き合うことなどで、自分の 視野をできるだけ広角度にして抢くという努力は 必要なようです。

自分の経験で言えば、夜の席の酒飲み話の中か ら思わ知恵に遭遇したこともありますし、職場 とは離れた方々との打付き合い、あるいは海外に 行ってそこの地物や人物に触れるという体験も、
自分の発想のベースを広くかつバランスよいもの にしてくれるのに効果があったのではと思いま す。つきるところ、とにかく良く勉強しなさい! ということになります。

\section{7.あとがき}

いろいろ、思い出しながら無䭾話を書いてみま した。この他にも興味を抱かれるかどうかは別と して、多くの事例を数多く経験し、話題も持って おりますが、ここらで止めておきます。

私が従事してきたトンネルの地下水問題は、性 格上多くの方々の目に触れるような形で公表され たものはあまりないようです。個々人が身につけ た貴重な経験は、本来何らかの形で継承されるべ きものだと思いますが、上記の理由もあって、な かなかうまく継承されていないというのが実態で す。この問題は、別に私の専門分野だけの問題で はなく、日本の学問や技術分野に抢いて今や共通 した問題となって扔ります。

今回の私の無駄話が、若い方々が参考にしてい ただけるものが少しでもあれば幸いと思いつつ終 わりといたします。

(受付：2008年 2 月 10 日、受理：2008年 3 月15日) 